Alvin L. Marty is a professor of econemics and finanee of the Center for Business and Government, Baruch College, City University of New York. Daniel L. Thornton is an assistant viee president at the Federeal Reserve Bank of St. Louis. Jonathan Ahlbrecht provided research assistance. the authors would like to thank, without implication, Phillip Cagan, David Laidler and Allan Melizer for comments on an earlier dratt.

\section{Is Thère a Case for "Moderate" Inflation?}

\section{Alvin L. Marty and Daniel L. Thornton}

T he proposition that inflation is a monetary phenomenon is more widely embraced now than it was three decades ago. Moreover, it is more widely accepted that inflation is subject to long-run control by the central bank. In recent years, the central banks of the United Kingdom, New Zealand and Canada have placed increased emphasis on teducing their long-run inflation rates. In the United States, former Rep. Steven Neal, D.-N. Carolina (House Joint Resolution 55. January 5, 1993), and Sen. Comnie Mack, R.-Florida, have proposed making stable prices the primary objective of the Federal Reserve.

Nevertheless, considerable opposition remains to making price stability the overriding objective of U.S. monetary policy. Some argue that the benefits of price stability do not watrant the cost of achieving it. For example, although extolling the virtues of price stability, Howitt (1990) is uncertain whether the benefits are worth the costs in terms of lost output (temporary, and perhaps permanent, due to hysteresis effects).

Although we are skeptical whether the empirical and theoretical analyses to date have correctly identified all of the benefits of price stability, this article addresses an issue that is logically prior to this one. Specifically, it addresses the question: If the inflation rate were zero, could society benefit from a higher rate of inflation? In other words, is modetate inflation preferable to price stability? Several arguments have been advanced that the economy benefits from moderate inflation. Recently, DeLong and Summers (1992) and Summers (1991) have suggested several rationales for why a central bank would choose moderate inflation over price stability as its long-run policy goal.

This article addresses four reasons that have been suggested to prefer moderate to zero inflation:

1. Moderate inflation enhances the stability of the economy.

2. Moderate inflation results in a higher steady-state level of output per person.

3. Moderate inflation increases the efficiency of inter-industry labor market adjustments.

4. Inflation enhances the efficacy of countercyclical monetary policy by allowing the real rate of interest to be negative, thereby stimulating effective demand in periods of recession.

The first two of these arguments are wellknown to economists, but have received scant attention in pubtic debates. Moreover, they are framed within specific, although quite different, theoretical models, so it is possible to provide a rather definitive evaluation of their merit. The remaining two arguments have received considerable attention, and may play a role in any public policy debate regarding the desirability of making price stability the primary monetary policy objective. The conceptual frameworks for these arguments are not well-specified, however, so we try to shore up their analytical footing by proposing specific interpretations.

Before proceeding, several issues should be clarified. First, the hypotheses that there are economic benefits from moderate inflation considered here implicitly argue against a so-called Friedman Rule (Friedman, 1969), that is, the "optimal" rate of money growth is one that generates steady-state deflation. Nevertheless, this article is not specifically about the Friedman Rule. Analyses of a Friedman Rule generally have been carried out in well-specified model economies.

Second, although the last two arguments for moderate inflation lack explicit theoreti- 
cal foundations, this has not prevented them from achieving an intellectual status among some economists and policymakers. The lack of theoretical foundations forces our analysis to range from the fairly technical to the somewhat conjectural, so that we may not provide a definitive evaluation of these arguments. In this case, we are content to present an analysis of these arguments.

Third, the arguments for moderate inflation analyzed here are based on the assumption of a fully anticipated, steady-state inflation. Although such inflations do not characterize real-world economies, we make this assumption until it is relaxed when we discuss the reasons why price stability is preferable to moderate inflation.

Fourth, the phrase "moderate inflation" is not well-defined. Some might consider moderate inflation to be 2 to 3 percent. For others, any rate under 5 percent could be moderate. Still others may deem anything less than double-digit inflation moderate. We suggest 5 percent as the break point for moderate inflation in the United States.

Finally although we used the phrases price stability and zero inlation interchangeably, we are aware that price stability is different and more stringent than zero inflation. Price stability implies that jumps in the price level are reversed; zero inflation need not.

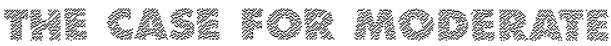

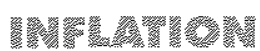

\section{Is Shabilly of he Economy whanced by Moderate inflotion?}

The first argument for moderate inflation is that certain stability conditions are sturdier at a high-money (nominal) rate of interest, making the economy less vulnerable to various shocks. Understanding this argument requires an understanding of the notion of stability upon which it rests. To illustrate, suppose that the real rate of interest suddenly rises, say, becautse of an increase in expected future profits. Given the underlying rate of inflation, this raises the money rate of interest, reducing the quantity of real money balances that individuals desire to hold. As individuals attempt to reduce their holdings of real balances, prices rise still further, fueling expectations of lurther inflation. This reduces the quantity of real balances demanded still further, giving rise to a further increase in prices and so on. The question is: Under what conditions will this sequence converge?

The answer is: Self-generating inflation cannot occur if, as the price level rises, its rate of change declines. Holding the growth of the money supply constant, this condition is illustrated in Figure 1, which shows two plots of the change in the log of the price level, against the price level itself, $P$. In one case, the slope of the curve rises with $P$. In this instance, the sequence witl not converge and the ultimate solution is the trivial one; the demand for real money balances approaches zero. In the other case, the slope of the curve decreases as $P$ increases, so that the sequence converges to a steady rate of inflation.

The argument that inflation enhances economic stability is an argument about the demand for money. To see this argument, assume that the demand for real money balances is solely a function of the nominal interest rate, whereby the nominal interest rate equals the constant real interest rate plus the actual rate of inflation (which is fully anticipated). Cagan (1956) showed that the rate of inflation decreases as the price level tises if $\alpha \beta<1$. The parameter $\alpha$ is the semi-log slope of the demand for real money balances with respect to the nominal interest rate, that is, percent change in the demand for real money balances per percentage point change in the money interest rate $(d \ln (M / P) / d t)$. The parameter $\beta$ is the rate at which individuals revise their expectations of inflation under adaptive expectations, $d E / d t=\beta(\pi-E)$, where $\pi$ and $E$ are the actual and expected rates of inflation, respectively.

If $\alpha \beta<1$ and the expected rate of inflation is initially greater than the actual rate, expected inflation falls until a stable steady state is reached at which the expected rate of inflation is equal to the actual rate. If, however, $\alpha \beta$ is greater than unity and actual inflation is initially greater than expected inflation, both expected and actual inflation grow without limit with real balances falling. 


\section{(1)}

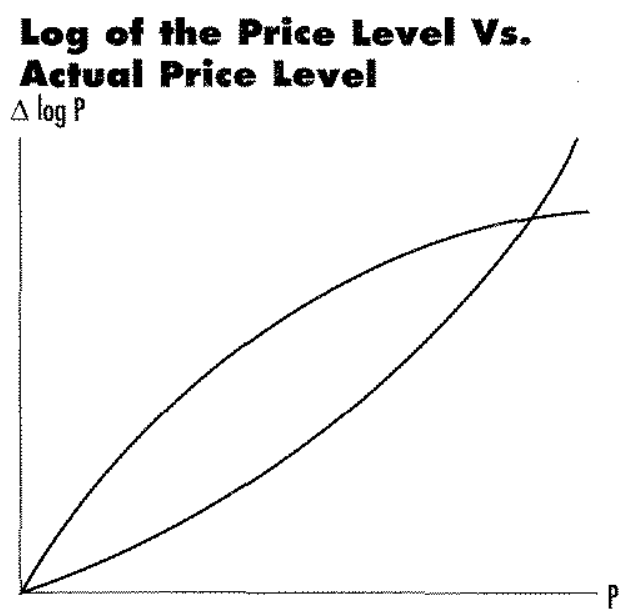

On the other hand, if $\alpha \beta>1$ and actual is initially less than expected inflation, both actual and expected inflation fall without limit. The steady state at which the actual and expected rate are equal is unstable.

\section{Srabilly Through Moderote Infionion}

If $\alpha$ and $\beta$ are constants, the stability conditions will be invariant to the steadystate inflation rate. Consequently, the suggestion that the stability conditions are sturdier at non-zero rates of inflation is an argument that either $\alpha$ or $\beta$ is inversely related to the steady-state inflation rate. Specifically, it was argued that $\alpha$ should be smaller at higher rates of money interest. That this may be so comes from noting that the elasticity of the demand for real money balances with respect to the money interest rates, $e_{m}$ is equal to $\alpha i$, where $i$ is the money interest rate. Thus, if $e_{n:}$ is constant, $\alpha$ will decline as the rate of inflation and, hence, the money interest rate rises. All other things the same, the stability condition is more likely to be satisfied at higher rather than lower rates of money interest if the interest elasticity demand for real money balances is constant.

The widely used Cagan (1956) moneydemand function assumes that $\alpha$ is independent of the nominal interest rate. Cagan's function significantly underpredicted real money balances during periods when prices were or had been relatively constant, but performed well during periods of high infla- tion. ${ }^{2}$ This suggests that the underprediction was due to $\alpha$ being higher at low rates of inflation.

That $\alpha$ is inversely related to the steadystate inflation rate is plausible, but this does not imply that stability is more likely at higher rates of inflation. For example, it is plausible that individuals revise their expectations of inflation more rapidly at higher rates of inflation, that is, that $\beta$ is positively related to the inflation rate. Indeed, Bruno (1989) provides some empirical support for a positive association between $\beta$ and the rate of inflation. Consequently, it is not necessarily the case that stability is greater at high inflation rates. An inflation-induced fall in $\alpha$ might be just offset, or perhaps more than offset, by an inflation-induced rise in $\beta$. Using adaptive expectations, no general conclusion can be reached about the stability conditions and the steady-state inflation rate.

\section{Genting on the Wrong side of the Laffer Curve}

Bruno and Fischer (1990) have revisited Cagan's stability condition in the context of financing a given budget deficit solely through seigniorage from money creation. Although assuming that the deficit is financed solely through money creation is not realistic in developed economies like the United States, where other forms of taxation are available, the Bruno and Fischer assumption is a useful theoretical device which allows stability conditions to be anchored by two equilibria on either side of the Laffer curve. The Laffer curve is the recognition that tax receipts do not increase continuously with the tax rate. Beyond some point, receipts decline as a further increase in the tax rate results in a significant erosion of the tax base. Consequently, except at that unique tax rate where tax revenue is maxinized, there are two alternative tax rates and. tax bases that generate the same tax revenue: a low tax rate and a high tax base, or a high tax rate and a low tax base. Bruno and Fischer demonstrate that if $\alpha \beta<1$, a stable equilibrium is at the socially desirable low tax rate-high tax base point. If $\alpha \beta>1$, an equilibrium is at the socially undesirable
Note hot $\theta_{m}$ is constalat the money demand function is in dou-

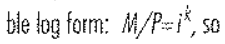
$\epsilon_{\pi}=\alpha i=k$

2 See Bailey (1956) and Findimat and Shworiz (1963) fat o discussion of the issae of the empiricat walitity of Cagaris morieyterinduld equation. 
point on the Laffer curve. Consequently, the argument is not whether the system is stable or explosive, but whether equilibrium is achieved at a socially desirable point on the Laffer curve.

\section{What If Expectotions Are Rotiond?}

From the condition that $E=\pi$, it is easy to see that rational expectations are the limiting case of adaptive expectations. Adaptive expectations approach rational expectations as $\beta \rightarrow \infty$. Consequently, if expectations are rational, the condition $\alpha \beta<1$ cannot be satisfied for any value of $\alpha$. In Cagan's world, the system explodes. In the Bruno and Fischer world of a fixed real deficit, a stable equilibrium (if it exists) is achieved at a high inflation rate on the wrong side of the Laffer curve. Under rational expectations, any affect on $\alpha$ is completely overwhelmed by $\beta$, which is infinite.

It appears that nothing remains of the argument for stability through inflation. In the case of adaptive expectations, any possible reduction in $\alpha$ due to inflation may be offset by an increase in $\beta$. If expectations are rational, an infinite $\beta$ swamps any effect of inllation on $\alpha$. Indeed, the stable equilibrium is at the socially undesirable side of the Laffer curve, that is, at a high rate of inflation (tax rate) and a low level of real cash balances (tax base). In particular, no argument can be made that moderate inflation produces stability on the socially desirable side of the Laffer curve.

\section{Does Modercte Inftohion Lead to o Higher Level of Oumu?}

The second argument for moderate inflation, that it leads to a higher level of steadystate output and consumption, was first formulated by Tobin (1965). The essence of Tobin's model is that in a growing economy, non-interest bearing real money balances augment disposable income. Given that the propensity to save out of disposable income is less than unity, an increase in real balances, all of which must be saved, gives rise to smaller saving in the form of physical capital. In Tobin's portfolio-balance model, real money balances and physical capital are substitutes. A higher anticipated rate of inflation induces individuals to economize on their holdings of money balances, freeing up savings for capital accumulation. This leads to a higher steady-state capital/abor ratio, resulting in higher consumption per person so long as the steady state is not pushed beyond the point where consumption per person is maximized (the so-called Golden Rule point).

The Tobin effect, that higher inflation induces higher levels of capital, output and consumption per worker, is open to a number of objections. For one thing, it is dependent on Tobin's assumption that savings are a constant proportion of income. If the savings rate is directly reduced by higher inflation, the Tobin effect can be reversed-even in the framework of Tobin's model (Dornbusch and Frenkel, 1973). Moreover, the Tobin effect is model-specific. The effect is absent in Ramsey-type models, in which the marginal product of capital is tied to the representative agent's rate of time preference. In such models, the marginal product of capital defines a unique steady-state capitallabor ratio which is independent of the level of real money balances. It is now generally recognized that the results of both Tobin- and Ramsey-type models are sensitive to small changes in assumptions. Moreover, Orphanides and Solow (1990) show that different models or small changes in assumptions in a particular model deliver disparate conclusions about the Tobin effect.

Consequenty, it is impossible as a matter of pure theory to make a compelling case that inflation increases real output.

A crucial reason for the fragility of these results is that, by their very nature, these money-growth models are the wrong vehicles for analyzing the role of money in the economy and, hence, the effect of inflation on the economy. A striking example of this is provided by Tobin's model, which predicts that the highest level of output per person occurs in a barter economy, in which holdings of real money balances are nil. This result stems from not taking money seriously. Real money balances reduce transaction costs. They do this by overcoming the dou- 
ble coincidence of wants associated with barter and by conveying information (for example, Brunner and Meltzer, 1971).

Compared to a barter economy, the reduction in total transaction costs permits society to devote more of its scarce resources to production, raising output and the consumption of goods and leisure. By reducing marginal transaction costs, money also results in a higher level of trade and correspondingly higher levels of output. Although the development of Solow-type growth models was an important first step in the analysis of growing economies, it is not surprising that these onecommodity models fail to capture the importank role that money plays in real-world economies.

Thus far, we have contrasted money and non-monetary barter economies. In principle, similar effects occur when individuals are induced by a rise in anticipated inflation to reduce their holdings of real balances. If inflation induces individuals to hold fewer real balances, even if one were to accept Tobin's argument that inflation increases output per person, any increase would be at the expense of a loss to society of the services of real balances. In fact, if money enters the production function, the Tobin effect may well be reversed; inflation then reduces output per person, as in Stockman (1981).

Inflation may not only reduce the steadystate level of per capita output, it may reduce the growth rate of output itself. For if capital is appropriately defined more broadly to include human capital, as is done in recent endogenous-growth models, inflation reduces investment in human capital, as well as in physical capital. Reduced investment in human capital lowers the growth of efficiency per person, which reduces the growth rate itself (for example, Lucas, 1988; King and Rebelo, 1990; and Dotsey and Ireland, 1993). A small but permanent reduction in the growth rate due to inflation has an adverse effect on output levels. This continual effect on output levels is more significant than any effect of inflation on the one-ime altering of the level of output per capita explored in earlicr exogenous-growth models.

Once we leave purely theoretical-growth models, and look at real-world economies, we must deal with how inflation interacts with real-world institutions. It has been shown that the interaction of inflation with a less-than-fully indexed tax system works to discourage capital accumulation (Feldstein, 1976, 1979; and Tatom, 1976).

The bottom line is that even within the framework of theoretical-growth models, the Tobin effect is subject to small changes in assumptions. When real-world institutions are included in the analysis, the weight of evidence is that inflation discourages capital accumulation. The Tobin effect is reversed. When capital is defined more realistically to. include human capital, the effect of inflation is to continually reduce the levels of output per person below what they would have been under stable prices.

\section{Does Modercie Inhation Enhance Relative Medi Wage Adjustments?}

The third argument for moderate inflation (Tobin, 1972; Schultze, 1985; Lucas, 1989; DeLong and Summers, 1992; and Summers, 1991) asserts that declines in the price of commodities and in the real wage of workers specialized to a particular industry can be made with less friction in a world with moderate inflation than in a world of stable prices. It is argued that under moderate inflation, the decline in a product's price and in the real wage rate of workers can be accomplished through a rise in prices and money wages elsewhere.

The belief that inter-industry adjustments are smoother under a regime of moderate inflation rests on the view that laborers prefer a rise in the prices of wage goods to an absolute reduction in money wages. But why should this be the case? Workers experience an identical decline in real wages in both cases.

One answer depends on the existence of a money illusion: A decline in real wages brought about by a rise in the prices of wage goods is incortectly perceived as smaller than the same decline in the real wage that occurs through a reduction in money wages. The persistence of money illusion in a steady state of anticipated moderate inflation is difficult to rationalize. Moreover, recent evi-

\footnotetext{
"After a survey of theoretical models, Blanchad and Fischer (9989) condude: "Colowitions suggest, however, that the effects of chonges it the inflotion tode on corpift acturintion in modests of the type developed in this chapter alse very smoll. If intlation has system? otic efferts on copital toctmalnotion (ond these is orenificclly a negative associntion), it is probolly for reat sons not incluted so far. One likely ceason is that the tex systent is not gevind with restect to intontion:."
} 
dence (McLaughlin, 1994; and Lebow, Stockton and Wascher, 1993) suggests there is no dearth of nominal wage cuts, even during periods of moderate inflation.

Furthermore, firms in a declining industry may adjust workers' compensation without cutting wages. Compensation includes benefits and perks which can be adjusted relatively easily relative to wages in cases in which workers have an irrational fear of nominal wage cuts. In any event, we believe that for the resistance to nominal wage cuts to be widespread, it must be motivated by considerations deeper than a pure money illusion.

One possible rationale for such resistance is that workers feel they have some control over money wages but no control over the general price level. Consequently, the same reduction in the real wage rate due to reduction in money wages brings into play factors that workers believe they can negotiate, in contrast to an increase in the prices of wage goods, which they are powerless to affect.

The second possible motivation would interact with the first. Workers may have less knowledge of demand than do employers. Consequently, when the industry demand declines, workers may be concerned that the employer is mistepresenting the true state of nature to force an unnecessary reduction in money wages. In this case, a fall in the real wage rate due to a rise in the prices of wage goods elsewhere avoids triggering a signal-extraction problem.

We have endeavored to make the best possible case for moderate inflation as a device for smoothing inter-industry wage adjustments, but in doing so, we have. ignored the existence of a cushion on money wage declines even in a regime of stable prices. If we were to introduce technical progress, even under price stability, the average level of money wages would rise at a rate equal to the average increase in output per person. This provides a cushion mitigating the need for an absolute decline in the money wage.

Finally, we suggest the hypothesis that workers' resistance to nominal wage cuts is not independent of the inflation regime in which they live. Under stable prices, such cuts may become more frequent and workers will become more accustomed to and less distrustful of money wage cuts. Accordingly, any "Itubricant" that moderate inflation may provide to ease labor market frictions will become increasingly unnecessary in a zeroinflation regime.

Although the claim that moderate inflation facilitates inter-industry wage adjustments cannot be definitively rejected, it does not rest on compelling theoretical or empirical foundations. In any event, monetary policy is an inappropriate and ineffective instrument for dealing with labor market problems, such as market frictions or the suboptimality of the natural unemployment rate. The latter may be due to taxes on wages which make the after-tax real wage smaller than the before-tax marginal product of labor. The socially optimal amount of employment equates the disutility of labor to the before-tax real wage so that after-tax employment is sub-optimal. Moreover, high unemployment compensation increases time spent in "search unemployment." The drift to higher unemployment in Europe and Canada is unlikely to reflect a movement up a short-run Phillips curve produced by unanticipated deflation, but rather is due to an upward drift in the natural rate of unemployment. In this case, appropriate policies to reduce tnemployment are teforms in taxes and unemployment compensation, not monetary policy.

\section{Modercte Inthotion Whances the Countaryclicel Entricacy of Monatory Policy}

A fourth argument for moderate steadystate inflation is that it enhances the counter cyclical efficacy of monetary policy by enabling the Federal Reserve to make the real rate of interest negative. The argument that the efficacy of monetary policy is enhanced by a moderate rate of steady-state inflation stems from the recognition that the money rate can never be negative, so that in a non-inflationary environment, in which the real and money rates are equal, the best that monetary policy can do is to drive both the 
real and nominal rates of interest to zero. DeLong and Summers (1992) and Summers (1991) argue that in a zero inllation regime, monetary policy will be unable to produce a sufficiently large reduction in the real interest rate to restore full employment in times of large adverse shocks to aggregate demand.

Is this an important argument for moderate inflation? There are several reasons to think not. First, the argument is based on the belief that the monetary authority can exert considerable influence over real interest rates through the so-called liquidity effect, and that monetary policy works primarily, if not solely, through its ability to influence the real interest rate. According to this view, an expansionary monetary policy drives real interest rates down, inducing an increase in spending. But the extent and duration of the effect of monetary policy on short-term real interest rates is controversial, theoretically and empirically. The exchange between Ohanian and Stockman (1995) and Hoover (1995) highlights the difficulties with theoretical models of the liquidity effect. The empirical evidence on the liquidity effect is mixed. Work by Reichenstein (1987), Thornton (1988), Gordon and Leeper (1994) and Pagan and Robertson (1995) suggests the liquidity effect is relatively weak and short-lived, although research by Christiano and Eichenbaum. (1991, 1992), Cook and Hahn (1989) and Romer and Romer (1990) suggest a more significant effect of monetary policy on real short-term interest rates.

Second, it is difficult to argie that sufficient investment opportunities will not exist unless the real rate is negative. The issue is whether the economic outlook can become sufficiently pessimistic that the expected real return on longer-term investments is negative. That DeLong and Summers (1992) and Summers (1991) have raised it again suggests that this old debate is far from settled. Bailey (1971) argues that there will always be some investments that yield a small nonnegative return, even if a depressed economy were not expected to return to its steady. state growth path for a period of 10 to 20 years. If investment opportunities increase sufficiently at very low but positive interest rates, the efficacy of monetary policy is not impaired by a zero lower bound on the real interest rate. Bailey's argument suggests that credit demand becomes very large (essentially infinite) at very low real interest rates, so that the real longer-term interest rates do not have to be negative to significantly increase investment.

Finally, despite the empirical evidence to the contrary, there appears to be a faitly widespread belief that the Federal Reserve exerts considerable influence over real shortterm interest rates, but much less influence over longer-term interest rates (see, for example, Goodfriend, 1993: and Greenspan, 1993). If monetary policy cannot make the long-term rate negative, it is natural to ask: Is there any gain from the possibility that the Federal Reserve may be able to make shortterm interest rates thegative for temporary periods? In markets in which there are few impediments to the flow of funds between the long and short end of the market, consistency of expectations requires that the current long-term interest rate be equal to the expected average of futtre short-term rates plus a risk premium. The risk premium is affected by a number of things, including uncertainty about future short-term interest rates.

If the market believes that the policy does not signal an increase in policymakers' desired steady-state inflation rates, people know that today's policy must give rise to reversals later. Whether the difference in the magnitude of the decline and subsequent rise in short-term interest rates in the zero and moderate inflation regimes will result in significantly different paths for real long-term interest rates under the iwo regimes is impossible to determine, a priori. Indeed, it is as easy to conjecture scenarios in which there would be no difference in the response of long-term real interest rates under the two steady-state inflation regimes as it is to conjecture scenarios in which there would be a significant difference. ${ }^{5}$

Given that it is unlikely that moderate inllation will enable the Federal Reserve to have a significantly larger effect on long-term real interest rates, and that very low or zero

\footnotetext{
4 Ho one would willingly trode 0 dot. lor far, $50 y, 95$ coats a year from now, so long os the sane dollor couth he held for o yect at zero carving cost.

5Indeed, Fuhrer and Madigan (1993) simulate the effect of more aggaessive policies thot result in negative shoriterm interest rotes and find very smath thenges in leng-term rates.
} 
real interest rates are likely to be sufficient for the Fed to offset adverse aggregate demand shocks, the argument that moderate inflation enhances the efficacy of monetary policy seems doubtful. If some role for inflation uncertainty is factored in, the idea that moderate inflation enhances the efficacy of monetary policy becomes even more tenuous.

\section{Why Zero millowion is preferable}

Although many estimate the output losses of moderate inflation to be modest, this issue is far from settled. In addition to the usual problems of measuring the permanent output losses, Dotsey and Ireland (1993) have shown that in a general-equilibrium analysis, the usual effects of inflation (the inefficient economizing on real money balances, substituting market activity for leisure, and redirecting resources from goods production to financial activities) compound to produce a significant output loss. Dotsey and lreland's result stems in part from the fact that inflation lowers real output growth. Although the effects on output growth appear small, compounded over time, they are significant.

Another compelling reason to prefer zero inflation is that higher inflation is associated with increased variability of both inflation and relative prices. The increased variability of inflation and consequent inflation uncertainty shorten contract lengths, thereby increasing contract costs. The greater variability also contaminates price signals, so the price system conveys less information. As the variability of inflation (associated with higher inflation) increases, it becomes more difficult to determine whether a particular commodity price change reflects a movement in the general price level, or a real shift in supply or demand resulting from taste and productivity shocks.

In addition, inflation and the higher variability of the general price level cause a reallocation of resources from the production of goods to financial services for the sole purpose of hedging against inflation. Even if there is no reduction in conventional measures of output, inflation produces a distortion of ottput. The banking system and financial service industries expand relative to other employment of resources such as industrial output, and households sacrifice leisure to reduce their real balances when the inflation tax rises. These effects call into question the notion that, by penalizing the consumption of priced commodities, inflation reduces work effort and increases leisure.

Although it is difficult to quantify the degree to which inflation impairs the ability of the price system to signal correct information, there is no doubt that the price system allocates resources most efficiently in the absence of inflation.

Moreover, zero inflation is preferable to moderate inflation because inflation, even moderate inflation, distorts accounting, legal contracts and the tax system. Inflation also distorts the true cost of inventories, the depreciation of plant and equipment, as well as the time profile of real mortgage payments, and other fixed-dollar denominated contracts.

Of course, this analysis assumes that taxes and private contracts are not indexed against inflation. Why, it may be asked, don't the authorities index taxes against changes in the price level so that real payments are unaffected? Why, in turn, doesn't the private sector index wages and fmancial contracts to nullify the impact of price changes?

In fact, the tax code is now partly indexed against inflation. Indexation, however, is often taken as a signal that the authorities are giving up the battle against inflation. This was the basis for the outspoken opposition to indexation by former Federal Reserve Chairman Arthur Burns and why the Bank of Canada has opposed indexation. It is easy to construct examples in which inflation-mitigating schemes, such as indexation by reducing the marginal costs of inflation, lead to an increase in the aggregate inflation rate. Morcover, foregoing indexation may be a help in developing a reputation for credibly pursuing anti-inflation policies (see, for example, Fischer and Summers, 1989). For these reasons, it is not clear that indexation of tax codes is desirable.

In the private sector, indexation is unlikely to occur. At the heart of the diffi- 
culty is a coordination problem. To be successlul, indexation must be implemented by a large number of diverse firms facing different information. For example, are price changes due to nominal or real variables? It is wellknown that indexing money wages to changes in prices due to teal shocks is undesirable. ${ }^{\circ}$ Are price changes permanent or transitory? Are the price changes industry-specific or global? It is unlikely that individuals will agree on the cause of a price change and then coordinate their actions. Given these obstacles, indexation in the private sector is difficult and, hence, fairly rare. Moreover, in instances in which private indexation is fairly widespread, as in Israel, it reduces the resolve to fight escalating inflation.

Finally, it is impossible to fully index real cash balances against inflation, as previousiy discussed, because inflation leads people to hold fewer cash balances and results in a loss of their services. ${ }^{.}$For these reasons, indexation is a frail reed on which to rest hopes of mitigating inflation's effects.

\section{Price Srobility as the Obiective of Monetary Policy}

Reducing an established moderate inflation trend may disrupt economic activity, producing temporary output and employment losses. Given an established moderate inflation rate, Howitt (1990, p. 104) argues that despite the desirability of zero inflation, the cost of achieving it probably outweighs the benefus. This argument against moving to price stability ignores the inflationary bias (and resulting uncertainty) that characterizes policy regimes motivated by concerns for transitional output and employment losses.

In the absence of a commitment to stable prices, a central bank concerned about transitional unemployment is likely to respond asymmetrically to shocks - temporary or permanent. This asymmetric behavior has clear implications for the price level in the case of demand shocks. A monetary authority concemed with transitional unemployment will be less willing to offset a demand shock that raises prices and employment than to offset an adverse demand shock that lowers prices and employment.
This asymmetric behavior extends to supply shocks as well. ${ }^{8}$ Adverse shocks will be accommodated; favorable ones will be ignored. Although the price level depends on many factors, including the relative incidence of positive and negalive shocks, concem for transitional unemployment leads a central bank to pursue policies that will cause the price level to be higher than it would be otherwise.

This asymmetric behavior creates an inflationary bias with the potential for accelerating inflation. As inflation increases, the monetary authority may be forced to tolerate transitional unemployment to bring the inflation down. Indeed, this appears to be what happened in the United States in the late 1970s and on a smaller scale in the late 1980 s. The best way to avoid such disruptions is to commit to a policy of stable prices.

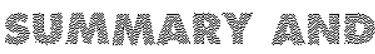

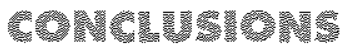

We have reviewed several. arguments in favor of moderate inflation and we find them to be lacking theoretically and, in some instances, empirically. The first argument, that moderate inflation enhances economic stability, is subject to compelling objections. If expectations are adaptive, any decline in the semi-elasticity of money demand associated with a higher inflation may well be offset by a more rapid revision of inflationary expectations. If expectations are rational, this must be the case.

The argument that inflation leads to a higher level of output is based on theoretical models that are not robust to small specification changes. When real-world institutions are taken into account, the weight of the evidence is that inflation discourages capital accumulation. When capital is defined to include human capital, inflation may reduce not only the level of output per capita but its rate of growth as well.

Also suspect is the proposition that moderate inflation increases the efficacy of monetary policy by allowing the central bank to make the real rate of interest negative. Sufficient investment opportunities are likely to exist at very low but positive real

\footnotetext{
"The nethorities in Istal indexed money woges to n price index whith included inforted goods. In fact, importad gyods shoold be exduded since changes in isipart prices refiect thunges in a segl wark able, the terms of trade. Later on, this mistake was rectified ond terrnts of trade effects were extluted from the price inter.

7 In principle, to maximize the serwees of reat botances, it would be desirathe to hive pices foll at the feal rote of interest and set the money rate of ingtesesi fo zeato. Peopie would thes bo induced to

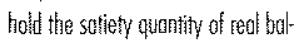
ances. It weuld gake us tee for ofieid, however, to discuss the merIts of deftation at the ted tote in comparison with statile prices. Therefene, we confine our utiention to a complesisen of zeto with noct. errte inflation.

${ }^{3}$ In the case of the oil stock in the 1970s (al odverse sumply shock which tended to nise infiftion and

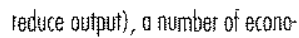
mists advocoter a cutantum? increase in the stock of wothey to affseä a potentiol incease in unemployneat. On the other tand, how ranay wices were trised in favos of a sedurtion in the money stock when OPEC collewsed?
} 
interest rates. Consequently, negative real rates are not required to make monetary policy effective. Also, even if positive inflation enabled the Fed to make real short-term interest rates negative, such actions may not lower long-term interest rates.

The proposition that moderate inflation eases inter-industry wage adjustments is weak too. One argument rests on the existence of a money illusion; we see no economic rationale for money illusion in the steady state. If the asserted resistance to nominal wage cuts is based on a deeper motivation, we suggest that it should disappear entirely as the regime of zero inflation persists.

Moreover, the evidence suggests that nominal wage cuts are frequent even during periods of moderate inflation. Hence, the conjecture that workers resist nominal wage cuts lacks both theoretical and empirical justification.

Finally, we argue that a policy of living with inflation camnot be rationalized on the grounds that there are transitory output costs associated with reducing inflation. A policy motivated by concern for transitional unemployment is likely to have inflationary bias that will erode a commitment to any price objective.

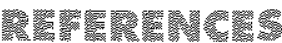

Bailey, Martin I. Notional Income and the Price Level: A Study in Macroeconomic Theory. MeGrow Hill, 1971.

"The Welfare Cost of Infletionary Finence," Jound of Politica Fonomy (Apil 1956), pp. 93-710

Blonchard, Otvier J., end Stanley Fischer. Lectures on Macroecononics. MII Press, 1989

Brenner, Koll, and Alan H. Meltzer. "The Uses of Money: Money in the Theory of an Exdhange Economy," The Ameritan Economic Review (December 1971), pp. 784-805.

Buno, Mittrel. "Econometrics and the Design of Econemic Reform," Econometrica (Mareh 1989), pp. 275306.

and Stantey Fischer. "Seinnionge, Operaing Rules, and the High intlation Trop," Quontetly Jound of Economics (Mhay 1990). pop. 35374 .

Cogon, Pilip. "The Monetary Dynamics of Hyper Inflotion," in Milton Frietmon, ed., Studies in the Quntity Theory of Money. Unvessity of Chicogo Press, 1956.

Ghistiono, Lowence 1., and Mortin Eichenbaum. "Lquidity Effects and the Monetory Trensmission Medhonism, "The American Economic Review (Moy 1992), pp. 346-53. and "Edentification and the liquidity Effect of a Monetay Policy Shock, "Wationd Bufeaus of Economic Research Working Paper No. 3920 (1991).

Cook, Timothy, and Thomus Holer. "The Effect of Chenges in the Federd Funds Rate Target on Market Interest Rotes in the 1970s," Jound of Monetory Economics (Nowember 1989), pp. 331-51.

Delang, J. Bredford, and Lawfence H. Summers. "Macreconomic Policy and Long-Run Growth," Federal Reserve Bank of Konsas City Economic Rewew (fourth quarter 1992), po. 529.

Donnbusth, Rudiges, and Jacob A. Frenkel. "Inflation and Growth: Altemofive Approaches," Jound of Money, Gredit and Benking (Februory 1973), DP. 141-56.

Dotsey, Miched, and Peter lredend. "On the Welfore Cost of Intlotion in Generd Fquilberm," unputhished monuscript (August 1993), Federol Reserve Benk of Ridmond.

Feddstein, Martin S. "The Weffore Cost of Petmonent thlotion and Optimal Shot-Run Economic Policy," Jound of Politicol Economy (August 1979), pp. 749-68.

"Inflation, Income Toxes, and the Rate of Interest: A Fiteoretical Andysis," The American Ecomomic Review (December $1976), 0 p .80920$.

Fischer, Stonley, and Lowrence H. Summers. "Should Nations Lean to Lue with Intlotion?" The Americon Economic Review (Moy 1989), pp. $382-87$.

Friedmon, Wilton. "The Optimum Quantity of Money," in The Optimum Qunotity of Money and Other Essoys. Aldine Publishing Co., 1969.

and Antin Jacobson Sctwatz. A Monefary History of the Unifed States 1867-1960. Princeton University Press, 1963.

Futrer, Jeff, and Brion Madigen. "A Monatary Policy When Interest Rates are Bounded at Zero," unpublished monusctipt (Auguss 25, 1993), Boad of Governors of the Federal Reserve System.

Goodfriend, Marvin. "Interest Rate Palicy and the Inflation Score Problem: 1979-1992," Federal Reserve Bonk of Richmond Economic Quorterly (winter 1993), p. 1. 124.

Gordon, Aavid B., and Fic M. Leeper. "The Dynemic Imparts of Monetary Polly: An Exereise in Tentative Ifentification," Journal of Poltical Economy (December 1994), pp. 1228-47

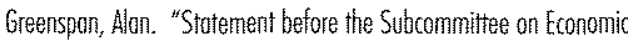
Growth and Credil Formotion of the Cormittee on Banking, Finatice and thban Aftoirs of the United States House of Representratives," Foderd Reserve Bullein (Septernber 1993), pp. 849-55.

Hoover, Kevin D. "Comnentory" this Review (Moy/June 1995), pp. 26.32

House Joint Resolution 55. "Oirecting the Federal Resene Open Merket Conmitte of the Federd Reserve System to Adopt and Pusue

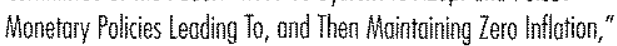
$103 r d$ Congress, 1 st Session (lanumy 5, 1993). 


\section{HeVIIII \\ JULY/AUEUST 199}

Howitt, Peter. "Zero Intlation as a Long-Term Target for Monetory Policy," in Richard G. Lipsey, ed., Zero Infiation: The Gost of Price Stoblity. C. O. Howe Institute, 1990

King, Robert G., and Sergio Rebelo. "Public Policy and Econonic Growth: Developing Neodassical Implications," Jounne of Political Econonty (October 1990, Part 2), pp. 5126-50.

Lebow, Dovid E., Dawid I. Stockton and Willom L Wascher. "Inflation, Naminal Wage Rigidity, and the Efficiency of Labor Markets," unputlished monuscipt (Auguss 1993), Boord of Gowennors of the Federd Reserve System .

Lucos, Robert E., Jr. "On the Hechonics of Economic Development," Journal of Monefary Economics (July 1988), pp. 342.

Lucas, Robert t. "The Bank of Conado and Zero Inflation: A New Cross of Gold?" Candion Public Policy (Marth 1989), pp. 84-93.

MLLughtin, Kenneth !. "Rigid Wages?" Journal of Wonetary Economics (December 1994), po. 383-414.

Ohanion, lee E, and Atan C Stockman. "Theoretical Issies of Liquidity Effects," this Revew (May/June 1995), pp. 3-25.

Orphonides, Atwonasios, and Robert M. Solow. "Woney, thilatien ond Growtr," in Benjomint H. Fredtnan and Frenk H. Hahth, eds., Hondbook of Monemary Econonics, wol. I. North-Holand, 1990

Pegon, Adrion R., ond Join C. Robetson. "Resolving the Liquidity Effect," this Review (May/lene 1995), pn. 3354.
Reicterstein, Witliem. "The Impat of Money on Shortterm Interest Rotes," Fconomic Inquiny (Jonuary 1987), pe. 67-82.

Romet, Christino $\mathrm{O}$., and Dowid H. Romer. "New Evidence on the Monetery Transmission Mechonism," Brookings Popers on Economic Activity (1990:1), ap. $149-98$.

Sthultze, Charles L. "Wicroaconomic Efficiency and Noninal Wage Stikiness," The Americun Economic Review (Mlard 1985), pp. 1-15.

Stackman, Alan C. "Antecipated Inflation and the Copital Stock in o Cash-in-Advane Economy," Journd of Monetary Economics (Noventer 1981), pp. 387-93.

Summers, Lowsence. "How Should Loner Term Honetory Policy Be Detemined?" Panel Discussion, Jound of Money, Gredtu und Bonking (August 1991, Pat 2), ap. 625-31.

Taten, John A. "The Welfore Cost of Inflation," this Review (Wewenther 1976), po. 922 .

Thanton, Daniel L. "The Effed of Monetayy Policy on Shotr Term Interest Rates," his Review (Moy/June 1988), pp. 5372.

Tobin, James. "Inflation and Unemployment," The Americon Economic Review (Mard 1972), pp. 1-18.

"Woney and Economic Growth," Ecomometrica

10ctober 1965), pp. 671-84. 